\title{
A Study on the Effect of Creative Chinese Characters Learning on the Ability to Learn Chinese Old Sayings and Idioms Using K-Pop Music Video
}

\author{
Eun-min Lee \\ MunSeong Middle School, Gwangju, South Korea
}

\begin{abstract}
Music is an extraordinary bridge between people all over the world so much as to be called a universal language. Idols and B-boys stages are fun, touching, and fantastic. Today, South Korean students are excited and enthusiastic about their colorful dance moves. The study is about creative educational methods that use K-pop music videos to learn the proverbs and old words that our ancestors learned to keep in mind and teach. K-pop lyrics are a rich reflection of the experiences of life and the world in which people are living today. Accordingly, this study can present new teaching and learning method examples that are used in class related to the old language associated with K-pop lyrics and can also introduce interesting class materials.

Keywords: K-pop music video, Chinese characters, creativity, high school learning methods, Chinese old sayings, Chinese idioms, modernization of Chinese characters
\end{abstract}

\section{Introduction}

"You have to change before you can overcome the crisis, change until you understand, and keep your original mind" ${ }^{1}$. The researcher looks into the words of the wise. How much do Chinese teachers teach the classics today to keep up with the changes of the times?

As we enter the 21st century, human beings are facing a wave of globalization and the rapid progress in knowledge and information. The characteristics of society in the 21 st century can be explained by information technology, globalization, and a lifelong learning society. The social changes are not only calling for a shift in the educational paradigm as well as daily life (Song, 2017). Moreover, education has been a passive and information-oriented education.

However, the education of the future society requires the students to be self-initiated and develop creative knowledge, thus making it necessary for teachers to change the educational paradigm through class innovation (Lee, 2018). Amid drastic changes in the educational paradigm, the Chinese language curriculum is a character discipline that develops the correct character and sensibility in students, such as literature and artistic performance.

The purpose of the Chinese language curriculum is to cultivate the correct character. This study aims to find a way for these Chinese characters to coexist and prosper with the various competing classes. For this purpose, we should not label the Chinese characters as a special subject. It must accommodate and integrate

Eun-min Lee, Master, Chonnam National University GwangJu; Teacher, MunSeong Middle School.

1 《周易》〈繫辭傳 (Gyesajeon) >: “窮則變, 變則通, 通則久。” 
various classes associated with Chinese characters (Lee, 2015). In other words, it combines the classics of Chinese with modern music and art.

In this study, it is defined as "Modernization of Chinese characters (MCC, 現前化)" when a person returns to the past and learns by restructuring what is past at this point in time. This is the past which has moved in the field of seeing now, not losing people to go back and has become the modernization (Na, 2009). K-pop music videos are very useful in MCC. It is because students can learn idiom originated in an ancient event (i.e., old saying) by combining them with K-pop music videos, and can trace them back to the past to explore the origin of the old saying.

"Old saying" means (1) a matter of great antiquity, (2) a phrase referring to a long time ago, (3) a rule that came from a long time ago, and (4) a Chinese word originating from an old story (Lee, 2018). The origin of old saying is derived from historical events that took place in the past. It also comes from the sage's words, proverbs, myths, legends, and folk tales. The number of letters in an old saying consists of at least two to a maximum of six characters. It should be used in clear distinctions from the idiom made with combinations of letters, which has no history.

\section{K-Pop Music Video as Educational Media}

Hallyu (Korean Wave) culture represents Korean contents. K-pop, which represents Korean popular music, is gaining attention all over the world. K-pop is making tangible and sophisticated strides. K-pop is a self-improving, entertaining, and moving tool that stimulates the eyes, ears, and other senses of the public. K-pop is breathing with the daily lives of Koreans. These days, people all over the world, including Koreans, are feeling sympathy and sharing. Starting with Psy's Gangnam style, countless Korean singers and idol groups, including Big Bang, Beast, BTS, Wanna One and Twice, are receiving much acclaim and love from people around the world.

Such attractive and great artistic content can also be actively used by teachers at school sites. In particular, if teachers use K-pop, it is likely that students will learn old sayings and idiom easily and interestingly that students find difficult. This is because students can naturally learn both old sayings and idiom and continue to be interested in them through their familiar content called K-pop. We are living in an era in which the age emphasizes and places emphasis on EQ (Emotional Quotient). K-pop can not only stimulate EQ, but also change the paradigm of education and give students creative wings by integrating popular culture into Chinese characters education. If this educational modernization is the driving force behind the development and establishment of the innovation in Chinese character classes, the education of Chinese characters will be more prosperous and the foundation will be expanded.

\section{The Appropriateness of Learning Chinese Characters Using K-Pop Music Video}

The appropriateness of learning creative Chinese characters including old sayings using K-pop music video can be found in two examples. First, according to the 2015 Ministry of Education's Notice Chinese characters and the revised curriculum, the methods for teaching and learning at middle and high schools are described as shown in Table 1. Item 6 of the curriculum explains the appropriateness of learning Chinese characters using K-pop music video (Department of Education, 2015).

\footnotetext{
2 “The present (現)" $\rightarrow$ In accordance with the present times, “previous (前)” $\rightarrow$ The classics of the past, "turn into $\sim($ 化)” $\rightarrow$ Recombing and utilizing in education.
} 
Table 1

2015 Revision Curriculum in Korean Education Law

Teaching and learning methods for middle and high schools

Article 6. Make learning easy and interesting for learners to learn, but present methods for teaching and learning with the following note.

- Using various media sources, the learning effects are enhanced, but teachers and learners can communicate bilaterally.

- The study-learning data is organized so that the student-oriented study is carried out by motivating the learners.

- Make sure that the study in the areas of "Understanding Chinese characters" and "Application of Chinese characters" is carried out systematically and collectively.

Second, according to a prior study (Back, 2014), K-pop music video is highly suitable for field teachers to use K-pop music videos in Chinese character classes. K-pop is not only able to excite students, but it is also capable of gaining a variety of classroom reactions by adding freshness to the class. Back (2014) describes the usefulness of K-pop in Chinese characters classes by citing the following examples.

\section{Case Study on the Old Sayings and the Short Message Study of Chinese Characters ${ }^{3}$}

Lee Eun-min's "A Chinese Character Class Using K-pop” is a class where students learn to find the old sayings related to the lyrics of songs. It focuses on making students listen to popular songs and learn the related Chinese characters so that they can improve their vocabulary and use them in their language lives. The teacher is constantly making public the class practices through several songs. Students often think of only classical languages when they think of the old sayings, so only when explanations are given about what the old sayings are, then will they learn them associated with the K-pop lyrics. This class is significant in that it has created interest among students by using their favorite K-pop as a learning tool and has applied the language they will learn in their daily lives. The examples are even more relevant, especially when Chinese character textbooks contain some of the more difficult essays that may be interesting to students after the 2007 revision and curriculum. While creating interest for learners through the popular K-pop lyrics each year, we hope to continue introducing classroom examples that demonstrate the exact origin and meaning of the term.

The above two examples demonstrate that K-pop music video can be a novel and creative way to learn old saying of Chinese characters.

\section{A Study on the Practical Use of Chinese Old Sayings and Idioms Lecture Using K-Pop Music Video}

When the class begins, it shows the students K-pop music video that will be used to learn old sayings and idioms of Chinese characters, and generates maximum interest and interest from the students. In the class development section, old sayings and idioms of Chinese characters related to K-pop lyrics are introduced along with their respective origins. It makes it easy to explain the outer and inner meanings of Chinese characters and encourages students to focus on them in a fun and meaningful way. At the end of the class, they read old sayings and idioms of Chinese characters learned using K-pop aloud to overcome the unfamiliarity of Chinese characters. Afterwards, students watches K-pop once again, and then finishes by internalizing the Chinese characters they studied. Figure 1 is a flowchart of Chinese old sayings and idioms lecture using K-pop music video.

\footnotetext{
${ }^{3}$ On November 2, 2013, the 20th Anniversary Conference of the Association of Korean Chinese Characters and Chinese Language Education Studies was held at SUNGSHIN Women's University under the theme "Retrospection and Exploration of the Theory and Practice of Chinese Language Education in Korea" and this paper was published on 27 April 2014 by modifying and supplementing the paper which was introduced at the conference.
} 


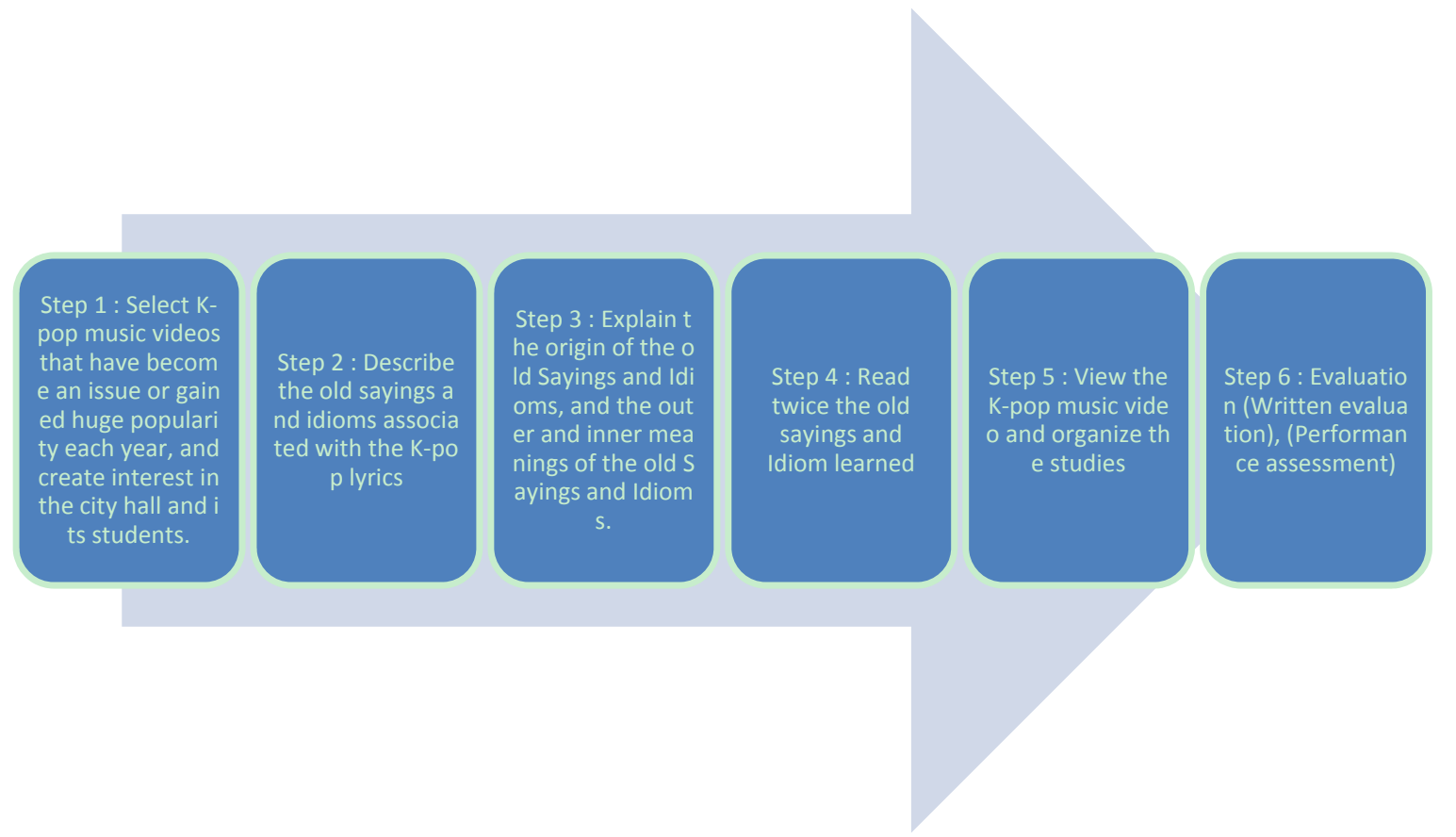

Figure 1. Flowchart of Chinese old sayings and idioms learning lecture.

Based on the flowchart of the adult language learning class using K-pop music video, the guidelines are organized as shown in Table 2.

Table 2

Direction of Chinese Old Sayings and Idioms Learning Class Using K-pop Music Video

\begin{tabular}{|l|l|l|}
\hline Learning process & Teaching and learning activities & Notes \\
\hline $\begin{array}{l}\text { Introduction } \\
(5 \text { min. })\end{array}$ & $\begin{array}{l}\text { Checking out K-pop handouts for today's study } \\
\text { Watching K-pop music video }\end{array}$ & $\begin{array}{l}\text { Students' checking } \\
\text { the handouts the } \\
\text { teacher prepared }\end{array}$ \\
\hline $\begin{array}{l}\text { Deployment } \\
(30 \text { min. })\end{array}$ & $\begin{array}{l}\text { Asking students to read one line at a time the lyrics they would like to study among } \\
\text { the K-pop handouts } \\
\text { After reading the lyrics of the song, explain the relevant contents and present the } \\
\text { related words. } \\
\text { Explaining in detail the origin of Chinese old saying that has the origin and guide the } \\
\text { students } \\
\text { Giving a detailed description of the outer and the underlying meaning of the related } \\
\text { Chinese old sayings and idioms } \\
\text { The students listen to the teacher's explanation and write the words in the blank } \\
\text { space on the handout. }\end{array}$ & $\begin{array}{l}\text { (1) Making the } \\
\text { presentation evenly } \\
\text { explaining the } \\
\text { relevant old sayings } \\
\text { and idioms }\end{array}$ \\
\hline $\begin{array}{l}\text { Finish } \\
(10 \text { min. })\end{array}$ & $\begin{array}{l}\text { Reading and organizing together all of the old sayings and idioms the students } \\
\text { studied } \\
\text { Internalizing the Chinese old sayings and idioms learned while watching K-pop } \\
\text { music video again } \\
\text { Performing the task of writing the learned Chinese old sayings and idioms twice in } \\
\text { their notebook, if time is available }\end{array}$ & $\begin{array}{l}\text { If time permits, guide } \\
\text { the students to carry } \\
\text { out the task } \\
\text { immediately }\end{array}$ \\
\hline
\end{tabular}

The researcher has been continuously learning Chinese old sayings and idioms using K-pop music video for about 10 years since 2007. Concretely, each year, the researcher selects popular K-pop that contains educational meaningful lyrics for the study. The K-pop list is organized as shown in Table 3. 
Table 3

List of K-pop Songs ${ }^{4}$

\begin{tabular}{|c|c|c|c|}
\hline Year of issue & Semester & Singers & Song title \\
\hline \multirow[t]{2}{*}{2007} & 1 & Cult-Three Musketeers & I'm Your Friend \\
\hline & 2 & Si-nae Yoon & Let's Study \\
\hline \multirow[t]{4}{*}{2008} & 1 & Yong-pil Cho & Let's Go on a Trip \\
\hline & & Soo Ra Jung & Republic of Korea \\
\hline & 2 & Wonder Girls & Nobody \\
\hline & & Yoon Do-Hyun Band & National Anthem \\
\hline \multirow[t]{4}{*}{2009} & 1 & Tae-woo Kim & Love Rain \\
\hline & & In Soon Yi & Goose's Dream \\
\hline & 2 & PSY & Champion \\
\hline & & Hani Kang & Just You \\
\hline \multirow[t]{2}{*}{2010} & 1 & $2 \mathrm{NE} 1$ & Clap It \\
\hline & 2 & Hwi Sung & I Even Thought About Getting Married \\
\hline \multirow[t]{4}{*}{2011} & 1 & Tae-woo Kim & Echo \\
\hline & & Hwi Sung & A Poignant Story \\
\hline & 2 & Super Junior & Mr. Simple \\
\hline & & Seung-chul Lee & Marley Flower \\
\hline \multirow[t]{4}{*}{2012} & 1 & PSY & Gangnam Style \\
\hline & & Taitiser & Twinkle \\
\hline & 2 & Primary, Baboon, Zion-T & See Through \\
\hline & & Big Bang & I Need a Girl \\
\hline \multirow[t]{3}{*}{2013} & 1 & Tae-woo Kim & Cosmic Girl \\
\hline & & Jong Shin Yoon & By Instinct \\
\hline & 2 & Hyolyn & Let It Go \\
\hline \multirow[t]{4}{*}{2014} & 1 & Zion-T & Yanghwa Bridge \\
\hline & & Hyo-shin Park & Field Flowers \\
\hline & 2 & Three Men & Toy \\
\hline & & Spring, Summer, Autumn, Winter & Bravo My Life \\
\hline \multirow[t]{3}{*}{2015} & 1 & Ye Eun Ahn & Mr. Mystery \\
\hline & 2 & Lee juck & Run in the Air \\
\hline & & Cho PD, In Soon Yi & My Friend \\
\hline \multirow[t]{4}{*}{2016} & 1 & $\mathrm{Na}$ Eol & Wind Memory \\
\hline & & Carnival & Well, Then. \\
\hline & 2 & Hyun Woo Ha & Lazenca, Save Us \\
\hline & & Bong-Gu & Where You Should Be \\
\hline \multirow[t]{5}{*}{2017} & 1 & PSY & I LUV IT \\
\hline & & Twice & Signal \\
\hline & 2 & Jong Shin Yoon & Do You Like it? \\
\hline & & Red-cheek puberty & We'll Be in Love. \\
\hline & & ВТОВ & Miss \\
\hline
\end{tabular}

The examples of learning materials using Psy's "I LUV IT" are as follows.

\footnotetext{
${ }^{4}$ The K-pop music video is available on YouTube (http://www.youtube.com).
} 


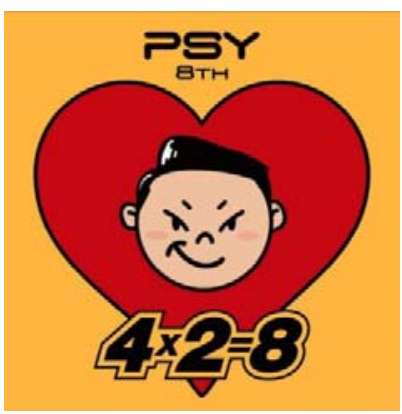

(1) At the age of 40 Babe: Lyrics of PSY's song

不惑之年 ${ }^{5}$ : Don't be carried away, the meaning of calling 40 years of age different, “Confucius”一爲政篇: It is an old saying, dating back to the days when Confucius was 40 years old and he was not tempted by worldly affairs.

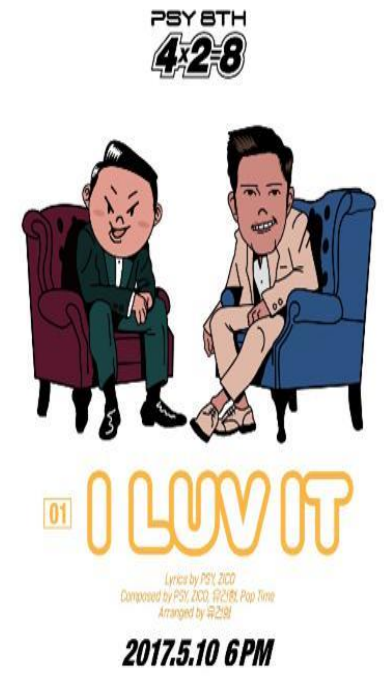

(2) My mother's precious child: Lyrics of PSY's song 金枝玉葉: The meaning of precious offspring

(3) Art rather than technology I LUV IT: Lyrics of PSY's song 技術不如藝術 ${ }^{6}$ : The meaning of loving art more

(4) Care kept me awake: Lyrics of PSY's song 輾轉反側 ${ }^{7}$ : The meaning of care is making me uncomfortable to sleep.

Figure 2 is an example of a handout actually used in the class.

\footnotetext{
5 不惑之年: 《論語》〈爲政篇 (The Confucian Analects)〉: This Chinese old saying stems from a description of Confucius' life by age on the side of the Confucian Analects.

6 技術不如藝術: The Chinese old saying is based on the Sentence structure of “百聞不如一見”. The meaning of the word “不如” is not as good as "B", which is a sentence that is expressed in the form of a comparison. This old saying is used to emphasize the importance of experience and is a phrase derived from the historical book, 《後漢書》.

7 輾轉反側: The Chinese old saying stems from〈關關㫿鳩〉 in 《詩經》 (The Book of Odes). The meaning of this term is to miss beautiful women and use it when you can't sleep.
} 


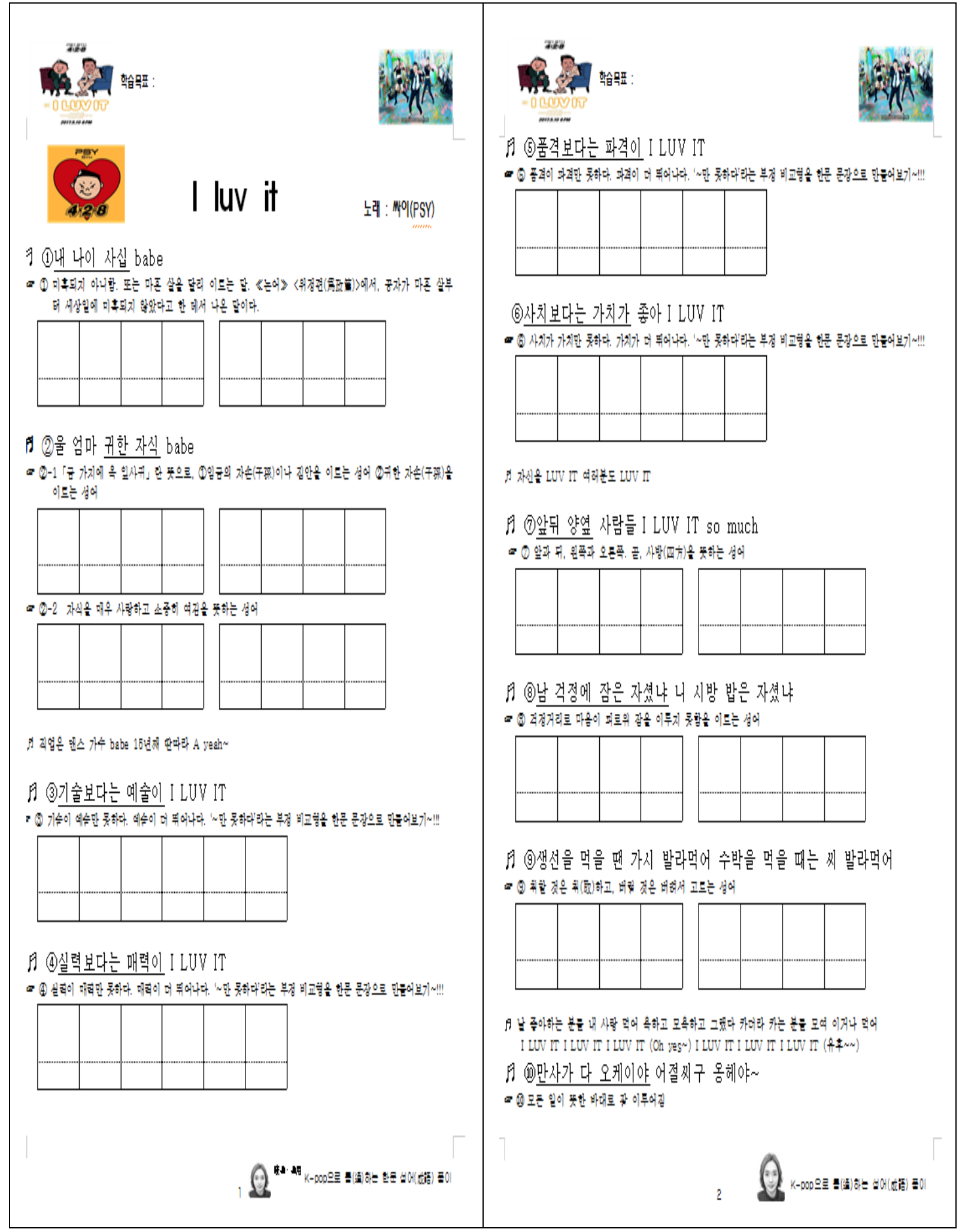

Figure 2. A case of the K-Pop handout. 
Figure 3 is a handout used by the actual student.

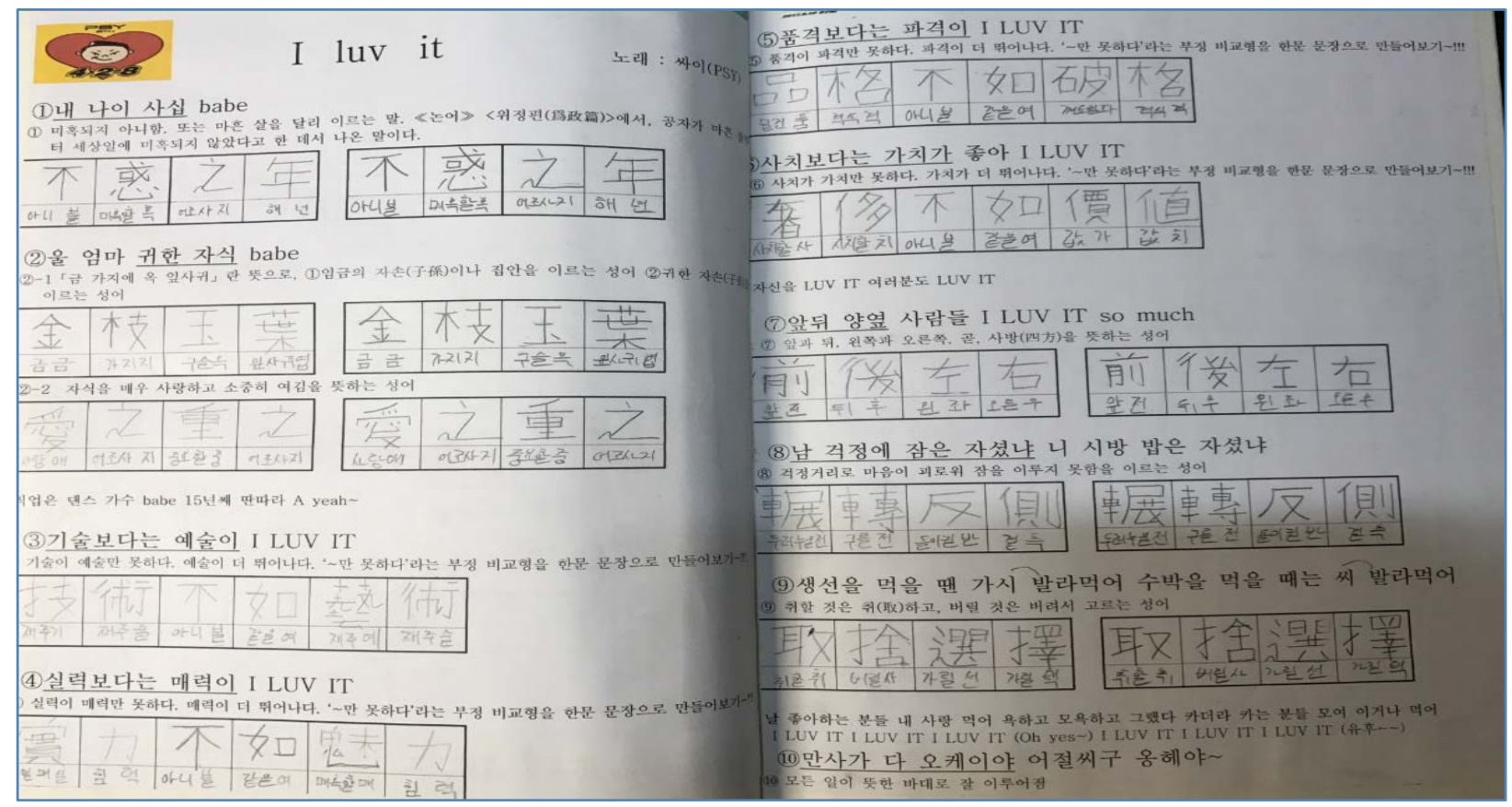

Figure 3. A case of the handout written by the students.

After learning Chinese old sayings and idioms using K-pop, a performance assessment was performed, and examples of performance evaluations are shown in Figure 4.

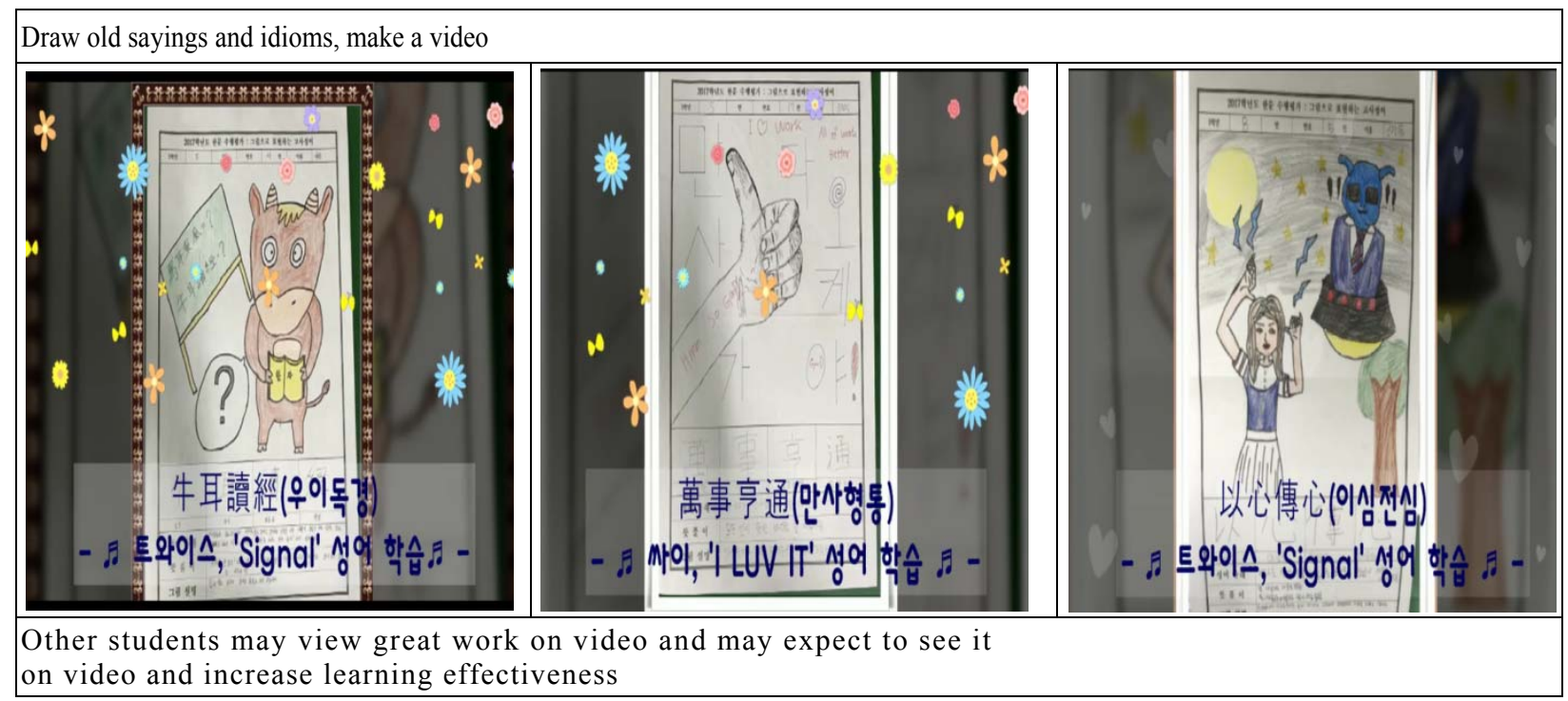

Figure 4. Example of Chinese old sayings and idioms learning performance using K-pop.

The performance evaluation consists of the following procedures. First, choose the old sayings and idioms that the students like themselves. The corresponding old sayings and idioms are then illustrated. They understand the origin, the outer meaning, and the inner meaning of old sayings and idioms as they expressed them in the picture. Finally, the students must explain why they chose to old sayings and idioms and what they wanted to express in the picture. 
From this performance assessment, the following meanings can be found: First, it is self-initiated assessment of practice. Second, they are personality assessments that reveal artistic and creative characteristics. Third, it is a procedurable process assessment closely related to real life and may maximize the effectiveness of performance evaluations.

\section{The Educational Effect of Creative Old Sayings and Idioms Learning Using K-Pop Music Video}

The educational effects of learning Chinese old sayings and idioms using K-pop music video are as follows.

First, it can increase the "flow rate". By incorporating Chinese characters into K-pop, the teacher was able to enhance the novelty of its classes and evaluations and enhance understanding of its contents. By increasing the flow of students, they were able to remember the Chinese old sayings and idioms for a long time. As a result, the correct answer rate in a written assessment was higher when students studied after using K-pop. Second, it can increase creativity. Creative thinking can be shown in the process of identifying the outer and inner meanings of Chinese characters and applying them to students' daily lives. The creativity of these students was reflected in drawings for Chinese characters. Third, linguistic playfulness was improved. When integrating Chinese characters into K-pop music videos, students naturally enjoyed playing the language. As a result, the students' interest in Chinese characters increased. Fourth, there is humanity. Learning Chinese characters using K-pop helped students build their character.

Table 4 shows the answer rate for the written test, which was increased after students studied Chinese characters using K-pop. 
Table 4

Answer Rate of the Midterm Exam and Final Exam of Spring Semester in 2017

\begin{tabular}{|c|c|c|c|c|c|c|c|c|c|c|c|c|c|c|c|c|c|c|}
\hline \multicolumn{19}{|c|}{ Answer rate comparison $(\%)$} \\
\hline \multirow[b]{2}{*}{ Test question } & \multicolumn{2}{|c|}{ Class 1} & \multicolumn{2}{|c|}{ Class 2} & \multicolumn{2}{|c|}{ Class 3} & \multicolumn{2}{|c|}{ Class 4} & \multicolumn{2}{|c|}{ Class 5} & \multicolumn{2}{|c|}{ Class 6} & \multicolumn{2}{|c|}{ Class 7} & \multicolumn{2}{|c|}{ Class 8} & \multicolumn{2}{|c|}{ Average } \\
\hline & midterm & final & midterm & final & midterm & final & midterm & final & midterm & final & midterm & final & midterm & final & midterm & final & midterm & final \\
\hline 13 & 90.3 & 84.3 & 90.6 & 90.3 & 86.6 & 93.5 & 83.8 & 83.8 & 96.7 & 93.5 & 93.5 & 93.5 & 90.3 & 90.3 & 83.3 & 80.6 & 89.4 & 90.0 \\
\hline 14 & 87.1 & 87.5 & 87.5 & 90.3 & 86.6 & 80.6 & 93.5 & 93.5 & 87.1 & 83.8 & 90.3 & 83.8 & 87.1 & 83.8 & 80.0 & 77.4 & 87.4 & 83.1 \\
\hline 15 & 90.3 & 87.5 & 75.0 & 93.5 & 73.3 & 93.5 & 87.1 & 77.4 & 83.8 & 96.7 & 83.8 & 93.5 & 87.1 & 83.8 & 80.0 & 90.3 & 82.6 & 90.8 \\
\hline 16 & 87.1 & 93.5 & 87.5 & 93.5 & 90.0 & 93.5 & 87.1 & 87.1 & 90.3 & 90.3 & 90.3 & 93.5 & 93.5 & 93.5 & 80.0 & 90.3 & 88.2 & 92.0 \\
\hline 17 & 80.6 & 83.8 & 84.3 & 83.8 & 80.0 & 83.8 & 90.3 & 87.1 & 80.6 & 83.8 & 96.7 & 87.1 & 83.8 & 87.1 & 80.0 & 80.6 & 84.6 & 84.8 \\
\hline 18 & 90.3 & 87.1 & 96.8 & 87.1 & 83.3 & 77.4 & 87.1 & 80.6 & 87.1 & 83.8 & 87.1 & 87.1 & 87.1 & 87.1 & 76.6 & 80.6 & 87.0 & 83.5 \\
\hline 19 & 90.3 & 96.7 & 90.6 & 96.7 & 90.0 & 93.5 & 87.1 & 87.1 & 93.5 & 93.5 & 96.7 & 93.5 & 96.7 & 93.5 & 90.0 & 83.8 & 91.9 & 91.2 \\
\hline 20 & 80.6 & 83.8 & 90.6 & 83.8 & 80.0 & 67.7 & 83.8 & 67.7 & 87.1 & 80.6 & 87.1 & 83.8 & 83.8 & 83.8 & 83.3 & 64.5 & 84.6 & 77.1 \\
\hline 21 & 93.5 & 83.8 & 96.8 & 83.8 & 90.0 & 74.1 & 90.3 & 74.1 & 96.7 & 83.8 & 96.7 & 77.4 & 90.3 & 77.4 & 86.6 & 74.1 & 92.7 & 79.1 \\
\hline 22 & 83.8 & 96.7 & 90.6 & 96.7 & 86.6 & 90.3 & 93.5 & 87.1 & 90.3 & 96.7 & 90.3 & 96.7 & 83.8 & 96.7 & 80.0 & 77.4 & 87.4 & 90.8 \\
\hline
\end{tabular}


According to Table 4, the answers for the final and mid-terminal achievements of the Chinese characters test questions that used K-pop music video are generally more than 80 percent. We can see that the students have a very high understanding of Chinese characters.

A survey was conducted on 224 third-year students from MunSeong Middle School in South Korea who had attended the actual class on Chinese characters using K-pop music videos. The survey was composed of students' interests, motivation, educational content, evaluations, and classroom satisfaction with Chinese characters learning. Table 5 shows the results of the survey.

Table 5

The Satisfaction of Chinese Characters Learning Using K-pop Music Video

\begin{tabular}{|c|c|c|c|c|}
\hline \multicolumn{5}{|l|}{ Interest and motivation } \\
\hline It is very fresh and interesting. & It is fresh and interesting. & Average & $\begin{array}{l}\text { It is not fresh and } \\
\text { uninteresting. }\end{array}$ & $\begin{array}{l}\text { It is not fresh and } \\
\text { uninteresting at all. }\end{array}$ \\
\hline$N=215$ & $N=5$ & $N=4$ & 0 & 0 \\
\hline \multicolumn{5}{|l|}{ Adequacy of the training contents } \\
\hline Be very significant & Be significant & Average & Be not significant & Be not significant at all \\
\hline$N=210$ & $N=8$ & $N=6$ & 0 & 0 \\
\hline \multicolumn{5}{|c|}{ Adequacy of the study assessments } \\
\hline It is very precise and fair. & It is precise and fair. & Average & $\begin{array}{l}\text { It is not precise and not } \\
\text { fair. }\end{array}$ & $\begin{array}{l}\text { It is not very precise and } \\
\text { not fair at all. }\end{array}$ \\
\hline$N=200$ & $N=20$ & $N=4$ & 0 & 0 \\
\hline \multicolumn{5}{|l|}{ Learning satisfaction } \\
\hline Be very satisfied & Be satisfied & Average & Be unsatisfactory & I am not satisfied at all \\
\hline$N=208$ & $N=14$ & $N=2$ & 0 & 0 \\
\hline
\end{tabular}

As we can see in Table 5, the satisfaction level of learning Chinese characters using K-pop has been very high across the list. It is therefore found that the classes are very effective in improving the quality of the classes. However, these methods and effects are still limited in their establishment as a generally structured theory. Despite the limitations of this research, the researcher has posted administrative materials on the "National Association of Chinese Language Teachers", a website for sharing Chinese language education, and shared a teaching method's study using K-pop music videos. Also, as a lecturer in Chinese characters, it is possible to promote the quality improvement of Chinese Language education by promoting the appropriateness of teaching method using K-pop music videos and demonstrating the actual classes. In addition, it is published in the Journal of Chinese Language Education to formulate a systematic theory on the teaching method's guidelines using K-pop music videos. Through these efforts, it is expected that the teaching method using $\mathrm{K}$-pop music videos will be widely used and ultimately established as a theory.

\section{Discussions}

The purpose of this paper is to verify that when constructing Chinese character classes using K-pop music videos, it can be used to create interest and encourage active participation among students to enhance their learning effectiveness. To achieve this research purpose, the paper reviewed the teaching methods and learning methods offered by the current Chinese language curriculum, and checked the compliance of Chinese character 
classes using K-pop music videos with the current curriculum. It also demonstrated that this innovative teaching method is effective in enhancing the learners' interest, interest in, and creativity in Chinese characters, using the actual examples of Chinese character education classes using K-pop music videos.

The main conclusions of this study are as follows: First, K-pop music video was an effective media that could stimulate the students' senses in terms of Chinese characters' learning, and the result helped them to overcome the negative perception of classical Chinese characters. This led to positive results, as students actively participated in the classes. The efficiency of the combination of K-pop music video and Chinese characters classes has been proven to be the result of high performance evaluations and a rise in the student's written test answers. The effectiveness and satisfaction of Chinese characters classes using K-pop videos were also supported by the results of the survey. Second, through Chinese language classes based on K-pop music video, students can gain an opportunity to appreciate the beauty and deep meaning of classical Chinese characters. Students were able to get rid of negative stereotypes about Chinese characters and find a sincere attitude towards the class. The modernization of Chinese characters was able to confirm that it was an essential choice for teaching and learning effectiveness. Third, in order to build a consensus with the students, the teacher of Chinese characters must continuously discover and develop content that is relevant to the current times. In other words, the deep Chinese language classes should be re-framed to fit the current trends, making it easier for students to see, understand, and enjoy. Above all, Chinese characters are a character subject that deals with the mental and natural characteristics of humans.

Through the conclusion of this study, it was found that the class using the medium of K-pop music video has a positive effect on learning Chinese characters in a very effective way. In addition, when applied to Chinese classes, the learners also found that the comprehension of Chinese characters and performance appraisals were very high.

By learning Chinese characters using K-pop music video and Chinese vocabulary and short language learning, we can broaden the base of learning Chinese characters and enhance the quality of Chinese language education.

\section{References}

Back, K. H. (2014). A study on the present situation and problems of Chinese characters training in the field. Association of Korean Studies, 34, 178-184.

Department of Education. (2015). Chinese characters and curriculum. Ministry of Education Notice, 74.

Lee, E. (2015). Wear clothes made of Chinese characters, education, and art. Gwangju Education Research, 15, 106-111.

Lee, E. (2018). A study on the "Dangun Mythology" current map using STEAM. A master's thesis, 5-6.

Lee, H. S. (2018). A major Korean dictionary (253). Seoul: Minjungseorim.

$\mathrm{Na}$, K. S. (2009). Find a path to the education of classical literature. Korean Language Education Association, 3-5.

Song, S. J. (2017). The development of western reform movement and alternative education movement. Retrieved March 20, 2018, from http://hanmun.eduhope.net/index.php and http:// www.youtube.com

詩經 (The Book of Odes): The oldest collection of Chinese folk songs from the old years of China.

周易 (The Book of Changes): One of the Confucian scriptures: 詩經 (The Book of Odes), 書經 (The Book of Documents), 易 經 (周易: The Book of Changes).

論語 (The Analects of Confucius): A book that collects the words and deeds of Confucius (孔子: B.C.551 B.C.479) and his disciples.

漢書 (The Literature of Han Dynasty): A historical book written by 班固 (B.C.32 92) in Han Dynasty. 